原

著

\title{
プロパフェノン鋔とフレカイニド錠の単回経口投与に よる発作性心房細動停止效果の比較研究
}

\author{
奥田健太郎 原田将英* 越川真行 市川智英 \\ 山本真由美 祖父江嘉洋 渡邊英一 尾崎行男
}

抗不整脈薬の単回経口投与による薬理学的除細動は, 薬物の長期投与による副作 用を回避し，心房細動 (AF) の症状やリスクを早期に軽減する目的で行われる，わ れわれは，日本人の AF 患者においてフレカイニドとプロパフェノンの単回経口投 与の有効性と安全性を検討した。発作性 AF 患者 29 例をフレカイニド $100 \mathrm{mg}$ (F 群, $\mathrm{n}=15 ; 65 \pm 15$ 歳), またはプロパフェノン $150 \mathrm{mg}$ ( $\mathrm{P}$ 群, $\mathrm{n}=14 ; 61 \pm$ 12 歳)にランダム化して単回経口投与を行い, 投与後 120 分間の除細動成功率を 比較検討した。患者背景は両群間で差を認めず，両群とも経時的な心拍数，血圧， QRS 幅, QTc 間隔の変動を認めなかつた。除細動成功例はF群で 3 例 (20\%), P 群で 7 例 $(50 \%)(p$ 值 = 0.09), 洞調律回復までの時間はF群で $70 \pm 17$ 分, P 群で $77 \pm 34$ 分であつた ( $p$ 値=0.74). F 群で (非) 通常型心房粗動 (心拍数 144/分) を 1 例認めた. F群の有効性が低かつたものの両群間で有意差を認めず，日本人の AF 患者に対して, 本研究の薬物投与量ではほぼ安全に単回経口投与が行えること が示された.

(心電図, $2016 ; 36: 5 １ 1$ )

\section{I .はじめに}

自覚症状を伴う心房細動 $(\mathrm{AF})$ が長時間持続すれ

\begin{tabular}{|ll|}
\hline Keywords & - 不整脈 \\
& ・心房細動 \\
& - 単回経口投与 \\
& - 抗不整脈薬
\end{tabular}

藤田保健衛生大学循環器内科

（† 470-1192 愛知県豊明市沓掛町田楽が窪 1-98)

*は責任者を示す(所属は著者に同じ)
ば，患者の QOLは低下する，また，心房筋の電気 的リモデリングが進行すれば $\mathrm{AF}$ は持続しやすくな り，心原性塞栓症のリスクが増加する。このため, 発症早期に $\mathrm{AF}$ を効率よく停止させることは, 症状 やリスクの軽減にとって重要である，抗不整脈薬の 単回経口投与法(pill-in-the-pocket) は AFの発症早

Efficacy and Safety of Single Oral Administration of Flecainide and Propafenone in Patients with Atrial Fibrillation

Kentaro Okuda, Masahide Harada, Masayuki Koshikawa, Tomohide Ichikawa, Mayumi Yamamoto, Yoshihiro Sobue, Eiichi Watanabe, Yukio Ozaki

2015年 3 月 13 日 原稿受領 $/ 2015$ 年 9 月 1 日 掲載承認 
期に治療を開始する目的で行われ，病院を受診する ことなく発作を自己管理することも可能となる．単 回経口投与法により治療費や入院回数の低下, 薬剂 の長期投与による副作用の回避, QOLの改善など が期待される。

Vaughan-Williams分類におけるIa，Ic， III 群の 抗不整脈薬を用いた単回経口投与の有効性が報告さ れており, 日本循環器学会の $\mathrm{AF}$ 治療(薬物)ガイド ラインでも, Ia群ないし Ic 群抗不整脈薬の単回経 口投与法はクラス II aの治療に分類されている ${ }^{1)}$.

フレカイニドとプロパフェノンは Ic 群に分類さ れる $\mathrm{Na}$ チネル遮断薬であり, $\mathrm{AF}$ の治療に広く 使用される. 欧米の臨床試験では，フレカイニドと プロパフェノンの単回経口投与法による発作性 $\mathrm{AF}$ の薬理学的除細動の有効性が報告されているが, 欧 米人と日本人では人種, 体格, 薬物投与量が異なる ため, 欧米の臨床試験の方法や結果を本邦での実臨 床に直接当てはめることはできない，本研究は，日 本人の発作性 $\mathrm{AF}$ 患者において，フレカイニドとプ ロパフェノンの単回経口投与法による薬理学的除細 動の有効性と安全性を前向きに検討することを目的 とした.

\section{II. 対象と方法}

動悸などの自覚症状からの発症後 48 時間以内と 推定される発作性 AF 患者 29例 (男性 17例, 女性 12 例，平均年齢 $63 \pm 13$ 歳)を対象とした。 $\mathrm{AF}$ の平 均心拍数が 70 拍 / 分以上で, 呼吸困難や失神など の症状がなく，血行動態が安定している患者が登録 された．除外基準は下記のとおりである; (1)年齢 18 歳未満, (2)左室駆出率(LVEF) 40\%未満, (3) QRS幅 0.10 秒以上の刺激伝導障害, (4)高度の房室ブロッ ク, 洞房ブロック，(5)狭心症，心筋梗塞，弁膜症， 心筋症, (6) WPW 症候群, 発作性上室頻拍, 心房粗 動, 8)拍数 150 拍 / 分以上の頻脈性, 9重症筋無 力症, (10)八ペースメーカ植込み, (11)腎機能障害 (血 清クレアチニン值 $1.5 \mathrm{mg} / \mathrm{dl}$ 以上), (12)血清カリウ ム $3.0 \mathrm{mEq} / 1$ 以下, 13妊娠または妊娠の可能性のあ
る女性，授乳期の女性，(14)過去に静注抗不整脈薬で 除細動に失敗したか，または心房粗動になった患 者, (15)脳塞栓の既往, (16) Brugada型心電図波形, (17)他の抗不整脈薬の使用. 患者は集中治療室 (CCU) に入院し, 胸部 X 線撮影, 血圧測定と 12 誘 導心電困記録を行った。次いで, 経胸壁心エコーと 経食道心エコーを施行し，特に器質的な疾患と心内 血栓のないことを確認した。 日本循環器学会のガイ ドライン ${ }^{1)} に$ 従いフレカイニドは $100 \mathrm{mg}$, プロパ フェノンは $150 \mathrm{mg}$ を無作為に割り付けて, 単回経 口投与を行った。 その後, 120 分間で 30 分ごとに血 圧測定と 12 誘導心電図記録を行い, 心拍数, QRS 幅, QTc 間隔を計測した。

本研究のプロトコールは藤田保健衛生大学の倫理 委員会にて承認され(10-167), 試験開始前に登録患 者全員から同意書を取得した。

本研究における結果は, 平均值士標準偏差で表記 した２群間の統計学的比較は, 連続数に対しては Student t-testを施行し, 非連続数に関しては $\chi^{2}$ 検 定を用いた。除細動成功率は Kaplan-Meier 法で評 価し，有意差検定には log-rank法を用いた。 心拍 数, 血圧, QRS 幅, QTc 時間の経時的変化は repeated measure ANOVA法を用いて比較した. いずれの検定においても， $\mathrm{p}<0.05$ を有意とした.

\section{III. 結 果}

\section{1. 患者背景因子の比較}

2009年 4 月から 2013年 4 月までに発作性 AF 患 者 29 例が登録され，フレカイニド $100 \mathrm{mg}$ (15例) またはプロパフェノン $150 \mathrm{mg}$ (14例)の単回経口投 与が行われた。両群の患者背景を表 1 に示す。平均 年齢はフレカイニド群で $61 \pm 12$ 歳, プロパフェノ ン群で $65 \pm 15$ 歳 ( $\mathrm{p}$ 值 $=0.5)$, 男女比はフレカイニ ド群で男性 10 例 / 女性 5例, プロパフェノン群で 男性 7例 / 女性 7例 ( $\mathrm{p}$ 值 = 0.36) であった. $\mathrm{CHADS}_{2}$ スコアはフレカイニド群で $1.6 \pm 0.9, \quad$ プロパフェノ ン群で $1.5 \pm 1.6(\mathrm{p}$ 值 = 0.84) であった。平均 $\mathrm{LVEF}$ は $53 \pm 9 \%$ であり，フレカイニド群で $51 \pm 9 \%$, 
表 患者背景

\begin{tabular}{|c|c|c|c|}
\hline & フレカイニド群 & プロパフェノン群 & $\mathrm{p}$ 值 \\
\hline 症例数 & 15 & 14 & \\
\hline 年齢(歳) & $61 \pm 12$ & $65 \pm 15$ & 0.5 \\
\hline 性別 (男性：女性) & $10: 5$ & $7: 7$ & 0.36 \\
\hline BMI & $25 \pm 6$ & $21 \pm 3$ & 0.02 \\
\hline \multicolumn{4}{|l|}{ 基礎疾患， $\mathrm{n}(\%)$} \\
\hline 高血圧症 & $7(47)$ & $4(29)$ & 0.05 \\
\hline 糖尿病 & $5(33)$ & $4(29)$ & 0.78 \\
\hline 脂質異常症 & $4(27)$ & $6(43)$ & 0.36 \\
\hline $\mathrm{CHADS}_{2}$ スコア & $1.6 \pm 0.9$ & $1.5 \pm 1.6$ & 0.84 \\
\hline \multicolumn{4}{|l|}{ 治療薬, $\mathrm{n}(\%)$} \\
\hline RAAS阻害薬 & $4(27)$ & $5(36)$ & 0.6 \\
\hline$\beta$ 遮断薬 & $6(40)$ & $2(14)$ & 0.12 \\
\hline Ca拮抗剤 & $4(27)$ & $4(29)$ & 0.91 \\
\hline スタチン & $4(27)$ & $3(21)$ & 0.59 \\
\hline 抗凝固薬 & $4(27)$ & $4(29)$ & 0.91 \\
\hline 抗血小板薬 & $3(20)$ & $2(14)$ & 0.56 \\
\hline \multicolumn{4}{|l|}{ 心エコー図検査 } \\
\hline LVEF (\%) & $51 \pm 9$ & $56 \pm 10$ & 0.24 \\
\hline $\mathrm{LVDd}(\mathrm{mm})$ & $46 \pm 7.2$ & $42 \pm 2.3$ & 0.17 \\
\hline $\mathrm{LAD}(\mathrm{mm})$ & $35 \pm 9$ & $38 \pm 10$ & 0.49 \\
\hline$E / E^{\prime}$ & $12.9 \pm 5.4$ & $11.5 \pm 7.4$ & 0.64 \\
\hline \multicolumn{4}{|l|}{ 血液生化学検查 } \\
\hline WBC $\left(10^{3} / \mu \mathrm{I}\right)$ & $7.8 \pm 4.1$ & $6.7 \pm 1.9$ & 0.39 \\
\hline $\mathrm{Hb}(\mathrm{g} / \mathrm{dl})$ & $13.2 \pm 2.7$ & $12.9 \pm 2.4$ & 0.74 \\
\hline Plat $\left(10^{4} / \mu \mathrm{l}\right)$ & $20.5 \pm 7.3$ & $21.8 \pm 7.7$ & 0.66 \\
\hline $\operatorname{ALB}(\mathrm{g} / \mathrm{dl})$ & $3.7 \pm 0.9$ & $3.6 \pm 0.6$ & 0.77 \\
\hline $\mathrm{T}-\mathrm{Bil}(\mathrm{mg} / \mathrm{dl})$ & $1.1 \pm 1.0$ & $0.8 \pm 0.2$ & 0.39 \\
\hline AST (IU/I) & $30.4 \pm 28$ & $30.5 \pm 11$ & 0.99 \\
\hline $\operatorname{ALT}(\mathrm{IU} / \mathrm{I})$ & $37 \pm 40$ & $32 \pm 17$ & 0.69 \\
\hline $\mathrm{BUN}(\mathrm{mg} / \mathrm{dl})$ & $22 \pm 23$ & $17 \pm 11$ & 0.38 \\
\hline $\mathrm{Cr}(\mathrm{mg} / \mathrm{dl})$ & $1.24 \pm 1.3$ & $0.8 \pm 0.2$ & 0.25 \\
\hline
\end{tabular}

ALB:アルブミン, BMI:body mass index, BUN:尿素窒素, $\mathrm{Cr}$ :クレアチニン, $\mathrm{Hb}$ : ヘモグロビン, $\mathrm{LAD}$ : 左房径, LVEF : 左室駆出率, LVDd: 左室拡張末期径, Plat: 血小板, RAAS：レニン-アンギオテンシンーアルドステロン系, T-Bil：総 ビリルビン, $\mathrm{WBC}$ : 白血球

プロパフェノン群は $56 \pm 10 \%(\mathrm{p}$ 值 = 0.24)であっ た。 また, 平均左房径 $(\mathrm{LAD})$ は $37 \pm 9 \mathrm{~mm}$ であり, フレカイニド群で $35 \pm 9 \mathrm{~mm}$, プロパフェノン群 で $38 \pm 10 \mathrm{~mm}(\mathrm{p}$ 值 $=0.49)$ と有意差を認めなかった.

\section{2. 除細動成功率と所要時間}

フレカイニド群とプロパフェノン群において治療 前(0分) と治療開始後 30 分, 60 分, 90 分, 120 分に
おける経時的な心拍数, 血圧, QRS幅, QTc間隔 の変動は認めず, 両群間でも有意差は認められな かった(図 1A〜E). 試験中 (120分間)に洞調律に 復したのは 10 例 $(34 \%)$ あり, フレカイニド群で 15 例中 3 例 $(20 \%)$, プロパフェノン群で 14 例中 7 例 (50\%)であったが，両群間で有意差は認められな かった ( $\mathrm{p}$ 值 $=0.09$, 図 2). 治療開始後から $\mathrm{AF}$ 停 止までの時間はフレカイニド群で $70 \pm 17$ 分, プロ パフェノン群で $77 \pm 34$ 分であった $(\mathrm{p}$ 值 $=0.74)$. 治療開始前の AF の心拍数は除細動成功例 (10例) が $127 \pm 22$ 拍 / 分, 不成功例 (19例) が $98 \pm 26$ 拍 / 分 であり，除細動成功例で有意に心室応答が速かった $(\mathrm{p}=0.007)$. 試験開始 120 分経過後に AFが停止し なかった 19 例 (66\%) はカーディオバージョンを施 行し, 全例洞調律に戻ったのちに帰宅とした。洞調 律回復後の QRS幅, QTc 間隔の值は, フレカイニ ド群でそれぞれ $105 \pm 20 \mathrm{msec}(\mathrm{p}=0.53), 439 \pm$ $37 \mathrm{msec}(\mathrm{p}=0.54), \quad$ プロパフェノン群で $100 \pm$ $11 \operatorname{msec}(\mathrm{p}=0.48), 429 \pm 37 \operatorname{msec}(\mathrm{p}=0.69)$ であり, 投与前に比し有意差を認めなかった. 1 力月後の外 来受診時に, 動悸をはじめとする自覚症状や心電図 などから再発が疑われた症例は, 除細動成功例 (10 例) で 3 例 (30\%), 不成功例 (19例) で 5例 (26\%) と, 両群間で有意差を認めなかった $(\mathrm{p}$ 值 $=0.8)$.

\section{3. 有害事象}

フレカイニド投与 120 分後, 心房粗動 (心拍数 144/分)を1例 (3\%)に認めた.

\section{IV. 考察}

Ic群のフレカイニドとプロパフェノンは Naチャ ネルに対する open channel blockerであり，チャネ ルと結合し解離速度が遅いため, 比較的強い $\mathrm{Na}$ 電 流の遮断作用を有する. 両薬剤は活動電位持続時間 が短い心房筋においてもその効果を発揮しやすいこ とから， $\mathrm{AF}$ の治療に広く用いられる。 $\mathrm{AF}$ 発作を 予防する観点からは継続的な内服治療が行われる が, 有効性と安全性には問題がある. Aliotらは発 作性 $\mathrm{AF}$ 患者 97 人に対してフレカイニドまたはプ 


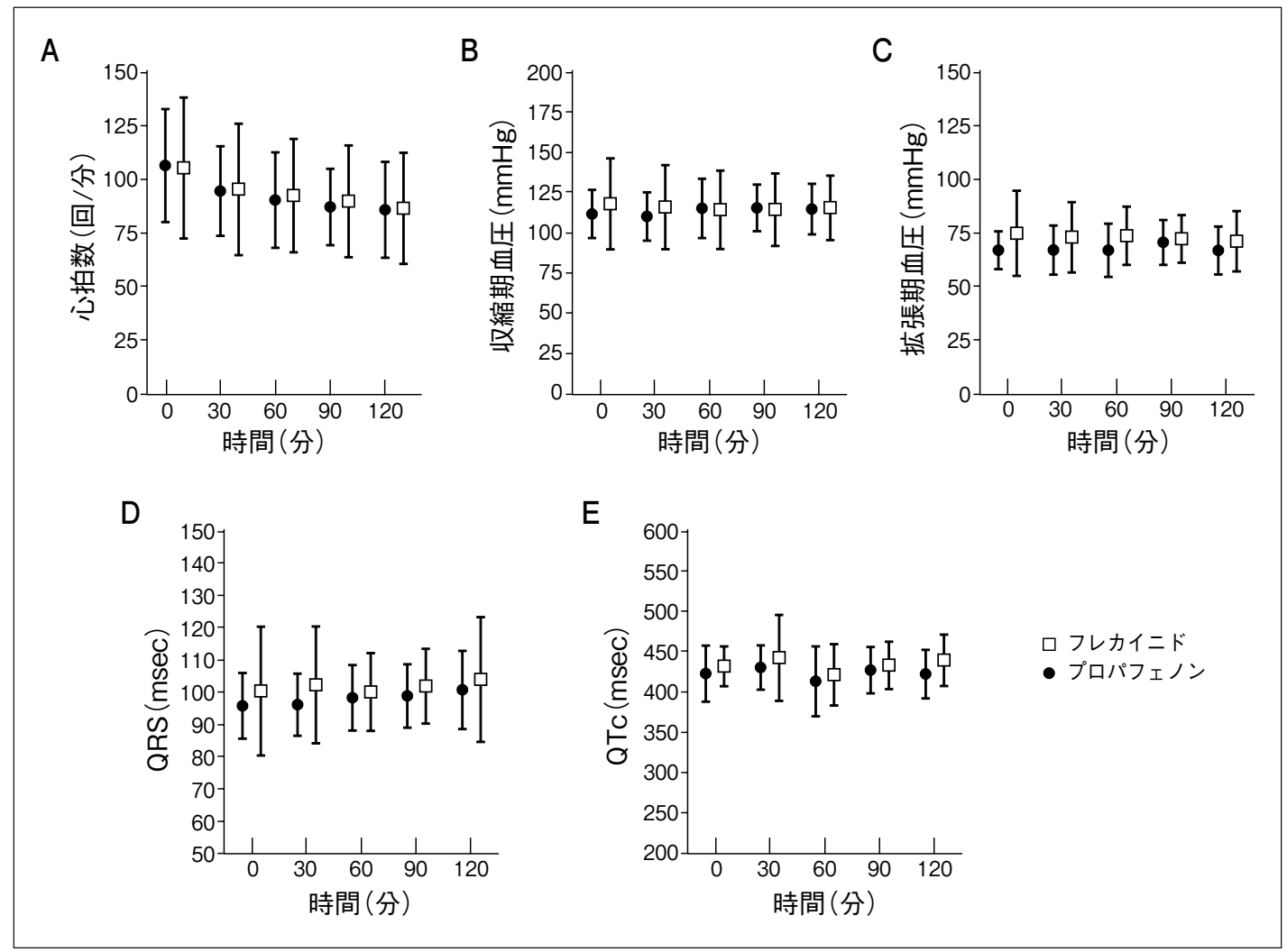

図 1 血行動態指標と心電図指標の経時的変化

各計測点での両群間の比較は，反復測定 2 元配置分散分析で解析を行い，有意差を認めなかった(交互作 用あり)。

A：心拍数. 0 分(投与前)， 30 分， 60 分， 90 分， 120 分に記録， B：収縮期血圧， C : 拡張期血圧， D： QRS 幅, E：QTc間隔.

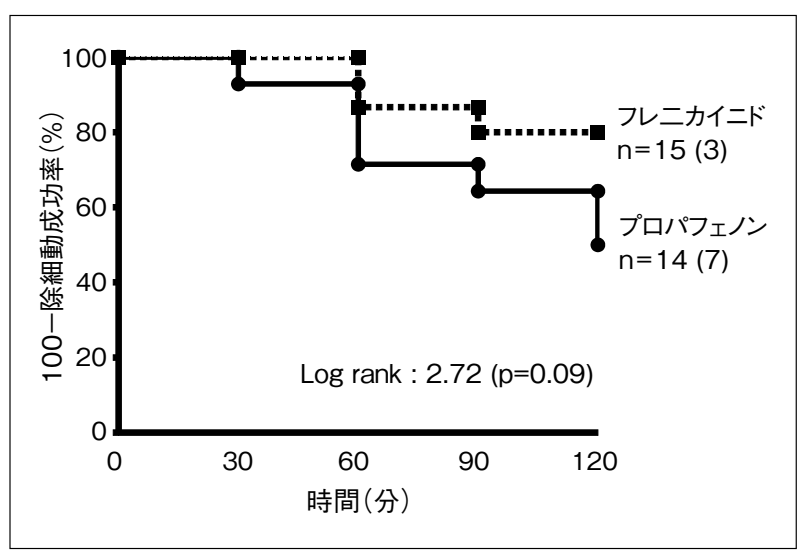

図 2 除細動成功率

0 分(投与前), 30 分, 60 分, 90 分, 120 分に㧍ける 100-除 細動成功率 $(\%)$
ロパフェノンを長期投与したが, 副作用や効果不十 分のために，1年後には死亡例を含む 45 例 (46\%)で 治療が中断されたと報告した ${ }^{2)}$. Chimientiらも長 期投与により約 $30 \%$ の患者が副作用や効果不十分 のため, 治療が中断されたと報告している ${ }^{3)}$. 欧米 の研究であり, 薬剤投与量が多いことが影響してい るとも考えられるが, 抗不整脈薬の長期投与の有効 性や安全性は十分とはいえない. 特に, 発作の頻度 が比較的少ない AF 患者に対しては，長期投与によ る副作用を回避しつつ, 可及的早期に症状やリスク を軽減するために，単回経口投与は有効な治療法と 考えられる。

Martínez-Marcosらはフレカイニド，プロパフェ ノン，アミオダロンの静注による $\mathrm{AF}$ 除細動効果を 
検討した。除細動成功率はフレカイニド $90 \% ， フ ゚$ ロパフェノン $72 \%$ ，アミオダロン $64 \%$ であり，急 性の除細動効果に関しては III 群より Ic 群の抗不整 脈薬のほうが高く, 単回経口投与にも適した薬剤で あることが示唆された ${ }^{4)}$. また, Capucciらは発症 早期 (7日以内)の $\mathrm{AF}$ 患者に対してプラセボ，フレ カイニド $(300 \mathrm{mg})$, プロパフェノン $(600 \mathrm{mg})$ の単 回経口投与を行った。除細動成功率は，治療開始 3 時間後でフレカイニド $59 \%$ ，プロパフェノン $51 \%$, プラセボ $18 \% ， 8$ 時間後ではそれぞれ $72 \% ， 78 \%$, 39\%であり，両薬剤ともプラセボと比較して有意に 高かった．治療開始から除細動までに要した時間は フレカイニドで $158 \pm 109$ 分，プロパフェノンで $165 \pm 119$ 分と両薬剤の有効性に差を認めなかっ た ${ }^{5) ， 6)}$. Alboni らは，発作性 AFの再発に対する自 宅でのフレカイニドとプロパフェノンの単回経口投 与の効果を検討した。両薬剤による除細動成功率は $84 \%$ と高く, 副作用の発現率は $7 \%$ と長期投与と比 較して低かった，AFの発作による救急や病院受診 率も有意に低下し，外来治療としての両薬剂を用い た単回経口投与の安全性と有効性が示された ${ }^{7)}$. 単 回経口投与に関する過去の報告ではピルシカイニド $45 \sim 73 \%{ }^{8), 9)}$, フレカイニド $59 \sim 91 \%{ }^{5), 10)}$ ，プ

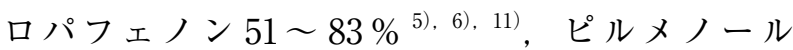
$44 \%{ }^{12)}$, シベンゾリン $67 \sim 75 \%{ }^{13), 14)}$ とされている. このうちピルシカイニド，ピルメノール， シベンゾ リンは我が国で臨床試験が行われているが，フレカ イニドとプロパフェノンを比較する試験は，われ われが知る限り本研究が初めてである.

本研究では, 日本循環器学会のガイドラインで推 奨されている薬物投与量を使用した。 しかし，本邦 における単回経口投与の臨床試験は限られており, 十分なエビデンスに基づいて決定された投与量では ない. Bottoらは, 発症早期 (72 時間以内) の発作性 $\mathrm{AF}$ 患者に対して，異なる投与量のプロパフェノン (450 mgまたは $600 \mathrm{mg}$ )を用いて単回経口投与を 行った。治療後 2 時間では, プロパフェノン $600 \mathrm{mg}(43 \%)$ が $450 \mathrm{mg}$ (8\%) と比較して有意に除
細動成功率が高かったが，4時間では両群間に有意 差を認めなかった $(57 \%$ vs. $46 \%)$ 。 また，両群とも 薬剤の副作用は認められなかった。 どちらの投与量 でも有効かつ安全ではあったが，プロパフェノン $600 \mathrm{mg}$ のほうがより速効性が期待できることが示 された ${ }^{15)}$. 日本人においても, 両薬剤の単回経口 投与法での安全性, 有効性が期待できる至適薬物投 与量の評価が必要であろう.

Alboniらは, フレカイニドまたはプロパフェノ ンの静注薬による治療効果や副作用の発現が, 同薬 剤を用いた単回経口投与の治療効果や副作用を予測 しうるかを検討している. フレカイニドあるいはプ ロパフェノンの静注薬治療により有効性と安全性が 確認された発作性 $\mathrm{AF}$ 患者に対して, 外来で同薬剂 による単回経口投与法を行った，79例における 213 の $\mathrm{AF} イ$ ベントに対して，94\%で単回経口投与が奏 功した。しかし，5例の患者(6\%)に副作用を認め， そのうち 4 例は初回治療で有害事象が発生した。静 注薬に対する反応が, 必ずしも単回経口投与の安全 性を保証するものではないことが示された ${ }^{16)}$. 本 邦においても単回経口投与は一般的に行われるよう になっているが，静注や長期投与とは別に有効性と 安全性の評価が必要であろう。

本研究では $\mathrm{AF}$ の初回発作例が多く, 単回経口投 与前に抗凝固療法が施行されていた症例は少ない (表). 日本循環器学会のガイドラインでは $\mathrm{AF}$ の発 作後 48 時間以内の除細動はクラス Iに分類されて おり，必ずしも抗凝固療法を必須としていない。本 研究も発作後 48 時間以内で, 明らかな基礎心疾患 や高度な心機能低下がない症例を登録しており， $\mathrm{CHADS}_{2}$ スコアはフレカイニド群で $1.6 \pm 0.9, \quad$ プロ パフェノン群で $1.5 \pm 1.6$ と比較的低かった(表). 入院後に経食道心エコーを施行しているが, 左房内 血栓を疑わせる所見は認められなかった．本研究の ような患者群に対しては, 抗凝固療法が未施行で も, 単回経口投与による除細動で血栓塞栓症が増加 するリスクは低いと考える。 しかしながら，基礎心 疾患を有する症例, 高度な心機能低下を伴う症例, 
$\mathrm{CHADS}_{2}$ スコアが高い症例などに対しては, 除細動 前の抗凝固療法の必要性について, さらなる検討が 必要であろう。

\section{V. 本研究の limitation}

登録患者数が 29 例と少なく，単回経口投与の有 効性と安全性を十分に評価するためには, 症例登録 数を増やす必要がある. 経口投与後の薬効動態とし ては，フレカイニドは $2 \sim 3$ 時間，プロパフェノン は $1 \sim 2$ 時間で最大血中濃度に到達する。本研究に おける観察時間は 2 時間であり, 十分な薬剤効果を 確認するには不十分であった可能性がある. 特に, フレカイニドはプロパフェノンょり最大血中濃度に 到達するのに時間を要するため，2時間ではフレカ イニドの効果を過小評価する可能性があり，このこ とがフレカイニドにおける低い除細動成功率に寄与 したかもしれない.また，フレカイニド群で $\beta$ 遮断 薬の併用例が多かったが, 薬物投与前の心拍数は両 群間で有意差を認めなかった．フレカイニド群と比 較して, プロパフェノン群で自律神経緊張の関与が 弱く, レートコントロールに $\beta$ 遮断薬を必要としな い例が多かった可能性があり，このことも除細動成 功率の差に影響している可能性がある. フレカイニ ド群では 1 例 $(3 \%)$ に心房粗動を認めたが, その予 防にはレートコントロール薬との併用が望まれる. 本研究では, 継続的な薬剤血中濃度を測定した症例 がなく，成功例のなかに自然停止例が含まれている 可能性は否定できない. より正確に薬剤の効果を確 認するためには, 対照薬(プラセボ群)の使用など, 評価方法の改善が必要である。また, 日本循環器学 会のガイドラインが推奨する薬物投与量を用いた が，欧米で用いられる量と比較するとかなり少な $\left(^{1)}\right.$. 薬物投与の前後で心電図指標に変化を認めな かったことから，より高い投与量を使用したとして も, 安全からより効果的な結果が得られる可能性が ある.したがって，単回経口投与における日本人に 適した投与量は，今後も検討が必要である.

\section{VI. をと め}

フレカイニドとプロパフェノンを用いた単回経口 投与における治療開始 2 時間後の発作性 $\mathrm{AF}$ の除細 動成功率はそれぞれ $20 \%, 50 \%$ でった. フレカ イニドの除細動成功率が低かったものの，有効性に 関しては両薬荗で統計学的な有意差は認めなかっ た.フレカイニド群で有害事象 (心房粗動)を 1 例に 認めたものの, 本研究の薬物投与量ではほぼ安全に 単回経口投与が行えることが示された.

\section{〔文献〕}

1) 循環器病の診断と治療に関するガイドライン $(2012$ 年 度合同研究班報告)：心房細動治療(薬物) ガイドラ イン (2013年改訂版). (http : //www.j-circ.or.jp/ guideline/pdf/JCS2013_inoue_h.pdf) (2016年 2月閲覧)

2) Aliot E, Denjoy I : Comparison of the safety and efficacy of flecainide versus propafenone in hospital out-patients with symptomatic paroxysmal atrial fibrillation/flutter. The Flecainide AF French Study Group. Am J Cardiol, 1996 ; $77: 66 \mathrm{~A} \sim 71 \mathrm{~A}$

3 ) Chimienti M, Cullen MT Jr, Casadei G : Safety of longterm flecainide and propafenone in the management of patients with symptomatic paroxysmal atrial fibrillation : report from the Flecainide and Propafenone Italian Study Investigators. Am J Cardiol, $1996 ; 77: 60 \mathrm{~A} \sim 75 \mathrm{~A}$

4) Martínez-Marcos FJ, García-Garmendia JL, OrtegaCarpio A, Fernández-Gómez JM, Santos JM, Camacho $\mathrm{C}$ : Comparison of intravenous flecainide, propafenone, and amiodarone for conversion of acute atrial fibrillation to sinus rhythm. Am J Cardiol, $2000 ; 86$ : $950 \sim 953$

5 ) Capucci A, Boriani G, Botto GL, Lenzi T, Rubino I, Falcone C, Trisolino G, Della Casa S, Binetti N, Cavazza M, et al. : Conversion of recent-onset atrial fibrillation by a single oral loading dose of propafenone or flecainide. Am J Cardiol, $1994 ; 74$ : 503 505

6 ) Khan IA : Single oral loading dose of propafenone for pharmacological cardioversion of recent-onset atrial fibrillation. J Am Coll Cardiol, 2000 ; $37: 542 \sim 547$

7 ) Alboni P, Botto GL, Baldi N, Luzi M, Russo V, Gianfranchi L, Marchi P, Calzolari M, Solano A, Baroffio R, Gaggioli G : Outpatient treatment of recentonset atrial fibrillation with the "pill-in-the-pocket" 
approach. N Engl J Med, 2004 ; 351 : 2384 2391

8 ) Atarashi $H$, Inoue $H$, Hiejima K, Hayakawa H : Conevrsion of recent-onset atrial fibrillation by a single oral dose of pilsicainide (Pilsicainide Suppression Trial on atrial fibrillation). The PSTAF Investigators. Am J Cardiol, $1996 ; 78: 694 \sim 697$

9 ) Kumagai K, Abe H, Hiraki T, Nakashima H, Oginosawa Y, Ikeda H, Nakashima Y, Imaizumi T, Saku K : Single oral administration of pilsicainide versus infusion of disopyramide for termination of paroxysmal atrial fibrillation : a multicenter trial. Pacing Clin Electrophysiol, $2000 ; 23: 1880 \sim 1882$

10) Capucci A, Lenzi T, Boriani G, Trisolino G, Binetti N, Cavazza M, Fontana G, Magnani B : Effectiveness of loading oral flecainide for converting recent-onset atrial fibrillation to sinus rhythm in patients without organic heart disease or with only systemic hypertension. Am J Cardiol, 1992; $70: 69 \sim 72$

11) Blanc JJ, Voinov C, Maarek M : Comparison of oral loading dose of propafenone and amiodarone for converting recent-onset atrial fibrillation. PARSIFAL Study Group. Am J Cardiol, 1999 ; 84 : 1029 1032

12) Atarashi H, Kuruma A, Ino T, Hirayama $Y$, Saitoh $H$, Hayakawa $\mathrm{H}$ : Clinical effects and pharmacokinetics of a single oral dose of pirmenol hydrochloride. J Cardiovasc Pharmacol, $1996 ; 27: 556 \sim 562$

13）島田恵，横塚 仁，井上宗信，小山卓史，小玉博明， 鈴木喜之, 大木貴博, 木村謙介, 真鍋知宏, 大橋成孝, 赤石 誠, 三田村秀雄, 小川 聡: コハク酸シベンゾリン 単回経口投与による発作性心房細動停止効果. 心電図, $2006 ; 26: 710 \sim 719$

14）戸叶隆司, 中里祐二, 土屋洋人, 林 英守, 佐々木玲聡, 関田学, 河野安伸, 安田正之, 住吉正孝, 代田浩之： 発作性および持続性心房細動に対するシベンゾリン経 口単回投与による薬理学的除細動に関する検討. 心電 図, $2009 ; 29: 50 \sim 57$

15) Botto GL, Capucci A, Bonini W, Boriani G, Broffoni T, Barone P, Espureo M, Lombardi R, Molteni S, Ferrari $\mathrm{G}$ : Conversion of recent onset atrial fibrillation to sinus rhythm using a single oral loading dose of propafenone : comparison of two regimens. Int $\mathrm{J}$ Cardiol, $1997 ; 58: 55 \sim 61$

16) Alboni P, Botto GL, Boriani G, Russo G, Pacchioni F, Iori M, Pasanisi G, Mancini M, Mariconti B, Capucci A : Intravenous administration of flecainide or propafenone in patients with recent-onset atrial fibrillation does not predict adverse effects during; pillin-the-pocket'treatment. Heart, 2010 ; $96: 546 \sim 549$

\title{
Efficacy and Safety of Single Oral Administration of Flecainide and Propafenone in Patients with Atrial Fibrillation
}

\author{
Kentaro Okuda, Masahide Harada, Masayuki Koshikawa, Tomohide Ichikawa, Mayumi Yamamoto, \\ Yoshihiro Sobue, Eiichi Watanabe, Yukio Ozaki \\ Department of Cardiology, Fujita Health University
}

Single oral administration of anti-arrhythmic drugs can control symptoms and risks of atrial fibrillation (AF) and can also prevent adverse events due to long-term treatment with anti-arrhythmic drugs. We evaluated the efficacy and safety of single oral administration of flecainide and propafenone in Japanese AF patients. Twentynine paroxysmal AF patients were enrolled and randomized to single oral administration of flecainide $100 \mathrm{mg}$ (Group-F, $\mathrm{n}=15 ; 65 \pm 15$ years old) or propafenone $150 \mathrm{mg}$ (Group-P, $\mathrm{n}=14 ; 61 \pm 12$ years old). There were no significant differences in characteristics between Group-F and Group-P patients. The time-course of heart rate, blood pressure, QRS duration, and QTc interval did not change during the observation period (120 min) in each group. The defibrillation success rates during the observation period were $20 \%(3 / 15)$ in Group-F and $50 \%(7 / 14)$ in Group-P ( $\mathrm{p}=0.09)$; the average time from single oral administration to sinus recovery was $70 \pm$ $17 \mathrm{~min}$ and $77 \pm 34 \mathrm{~min}$, respectively $(\mathrm{p}=0.74)$. Only one patient developed atrial flutter in Group- $\mathrm{F}$. In the present results, Group-F tended to show a lower defibrillation success rate than Group-P although the difference did not reach statistical significance. Flecainide $100 \mathrm{mg}$ and propafenone $150 \mathrm{mg}$ can be safely utilized for single oral administration in Japanese AF population.

Keywords : Arrhythmia, Atrial fibrillation, Single oral administration, Anti-arrythmic drug 